\title{
DETERMINANTY SATYSFAKCJI W OPINII KLIENTÓW MAŁYCH PRZEDSIĘBIORSTW USEUGOWYCH
}

\begin{abstract}
Streszczenie: Celem artykułu jest przedstawienie determinantów satysfakcji w ocenie jakości usług dokonywanej przez klientów przedsiębiorstw usługowych z sektora MSP. Pierwsza część opracowania zawiera charakterystykę pojęcia satysfakcji jako czynnika oceny jakości usług. Następnie zaprezentowane zostały wyniki anonimowej ankiety konsumenckiej, przeprowadzonej na grupie stu pięćdziesięciu klientów małych firm usługowych, dotyczącej determinantów kształtowania satysfakcji, której wyniki jednoznacznie wskazały na jej dużą istotność w ocenie jakości usług, budowanej głównie w oparciu o uwarunkowania techniczne (wśród mężczyzn) oraz organizacyjne (wśród kobiet), z uwzględnieniem niezawodności i ceny usługi.
\end{abstract}

Słowa kluczowe: jakość usług, MSP, rozwój, satysfakcja

\section{Wprowadzenie}

Działalność gospodarcza współczesnych przedsiębiorstw prowadzona jest w otoczeniu charakteryzującym się niestabilnością i dynamicznymi zmianami spowodowanymi wieloma czynnikami, wśród których dominuje duża konkurencja, globalizacja rynków oraz nieustannie zmieniające się potrzeby i oczekiwania klientów. Możliwość funkcjonowania i rozwoju przedsiębiorstw w tych warunkach zależy od szeregu istotnych determinantów, które wspomogą utrzymanie pozycji konkurencyjnej i przełamią bariery rozwojowe [1].

Szczególnym przypadkiem są małe przedsiębiorstwa usługowe. Sektor małych i średnich przedsiębiorstw $(M S P)$ stanowi filar rozwoju gospodarczego w Polsce. Inicjatywy, innowacyjność i rozwój przedsiębiorstw należących do tego sektora są wspierane i stymulowane. Ponadto, koncepcja trzech sektorów wskazuje na prawidłowość ekonomiczną zgodnie z którą obserwowany wzrost sektora usług będzie kontynuowany [2]. Wobec tego, wśród małych przedsiębiorstw usługowych notuje się ogromną konkurencję, z którą przedsiębiorstwa starają się walczyć przy pomocy różnorodnych narzędzi. Jednym $\mathrm{z}$ nich jest zapewnienie wysokiego standardu usług, w postaci jak najwyższej ich jakości.

\footnotetext{
${ }^{1}$ Mgr inż., Faculty of Management, Częstochowa University of Technology, Al. Armii Krajowej 19b, 42 200 Częstochowa, Polska, e-mali: kamilakowalik93@gmail.com, ORCID ID: 0000-0002-2808-0191

${ }^{2}$ Dr inż., Department of Production Engineering and Safety, Faculty of Management, Częstochowa University of Technology, Al. Armii Krajowej 19b, 42-200 Częstochowa, Polska, e-mail: dorota.klimecka-tatar@wz.pcz.pl, ORCID ID: 0000-0001-6212-6061
} 
Jakość usług stanowi obszerne zagadnienie jako rezultat dostosowania teoretycznych rozważań nad jakością do specyfikacji usługi [3]. W literaturze przedmiotu dostępnych jest pięć podstawowych zestawów charakterystyk tego pojęcia. Jakość usług w oparciu o definicje produktowe to korzyść dostarczana usługobiorcy. Podejście procesowe pojmuje jakość usług jako jej zgodność ze standardem. Aspekt filozoficzny odnosi się do doskonałości procesu działań usługowych. Zorientowanie na wartość określa jakość usługi jako korzyści wynikające z usług porównane do kosztów jej pozyskania. Rezultatem definicji popytowych, uznawanych aktualnie za najważniejsze $\mathrm{z}$ powodu ich zorientowania na klienta, jest powstanie opracowań przedstawiających jakość usług jako spełnienie potrzeb i oczekiwań klientów, które są przez przedsiębiorstwa kreowane i nieprzerwanie identyfikowane i mierzone [4].

\section{Satysfakcja klienta jako determinanta jakości usług}

Stosunkowo nowe zagadnienia dotyczące jakości usług wywodzą się z konieczności dostosowania problematyki jakości produkcji przemysłowej do realiów współczesnej gospodarki, która przestała postrzegać produkcję jako fundament rozwoju gospodarczego. Nowoczesne strategie i narzędzia walki konkurencyjnej za filar umożliwienia przedsiębiorstwu funkcjonowania i rozwoju przyjmują zapewnienie najwyższej jakości wyrobów, ponadto wymagając także jej wysokiego poziomu w zakresie dystrybucji, sprzedaży i serwisu [5]. Wynikiem zaistniałej sytuacji jest rozwój koncepcji teoretycznych dotyczących metodologii i doskonalenia jakości usług poprzez dostosowanie jakości produktu do specyfikacji usługi.

Jakość usług charakteryzuje się dużymi trudnościami w zakresie pomiaru z powodu obecności różnorodnych jej kryteriów, które uniemożliwiają przygotowanie uniwersalnego wzorca wskaźników wymiernych. Ponadto, za jakość usługi odpowiedzialny jest przede wszystkim usługodawca i nie występuje podział odpowiedzialności obecny $\mathrm{w}$ produkcji. Wspomnieć należy także o interakcji identyfikowanej pomiędzy usługodawcą i usługobiorcą, będącej istotnym uwarunkowaniem ostatecznej oceny poziomu jakości usługi przez klienta. Proces świadczenia usługi wykazuje także całkowity brak tolerancji błędów i uzależniony jest od zapotrzebowania [6].

Szczególną determinantą jakości usług jest satysfakcja klienta, która w ogólnych opracowaniach zawierających uwarunkowania jakościowe z zakresu produkcji charakteryzowana jest mianem użyteczności zależnej od parametrów i właściwości produktu, a w przypadku usług określana jest jako funkcja spełnienia indywidualnych oczekiwań klienta. 
Współczesne opracowania teoretyczne w dużym stopniu bazują na pierwszej charakterystyce tego pojęcia, sformułowanej w roku 1960 przez Theodora C. Levitta, uważającego, iż przeznaczeniem przemysłu jest zadowalanie klienta [7].

Wiele z nich podkreśla złożoną naturę satysfakcji, która powoduje konieczność oddziaływania przez przedsiębiorstwo zarówno na sferę poznawczą, jak i emocjonalną [8]. Sfera emocjonalna jest coraz częściej podkreślana jako dominująca determinanta satysfakcji, którą określić można jako odbierane przez zmysły zaspokojenie potrzeb klienta, który dzięki spełnieniu jego oczekiwań doznaje pozytywnych uczuć [9].

Kompleksowe opracowania wskazują na źródło tych odczuć, czyli wartość jaką dla klienta stanowi wynik skorzystania $\mathrm{z}$ danej oferty usługowej. W zależności od kryterium czasu powstawania satysfakcja klienta pojawić się może bezpośrednio po skorzystaniu z usługi lub jako rezultat jego reakcji na całość doświadczeń z tym związanych [10].

Warto wskazać na ścisłe powiązanie satysfakcji z pozytywnymi odczuciami klienta. W przypadku braku zadowolenia z jakości usługi, mówić należy o braku satysfakcji. Ponadto, pojawienie się satysfakcji uwarunkowane jest subiektywnymi uczuciami i emocjami klienta, który poziom zadowolenia kształtuje w oparciu o mierzalne atrybuty jakości, czynniki sytuacyjne (np. własne samopoczucie) oraz wewnętrzne standardy związane z potrzebami, normami i oczekiwaniami [11].

Rosnące zainteresowanie przedsiębiorstw pojęciem satysfakcji oraz wzrost jego znaczenia spowodowało szereg analiz związanych z mechanizmami jej powstawania. Najpopularniejszym modelem jest model kształtowania się satysfakcji klienta (rys.1).

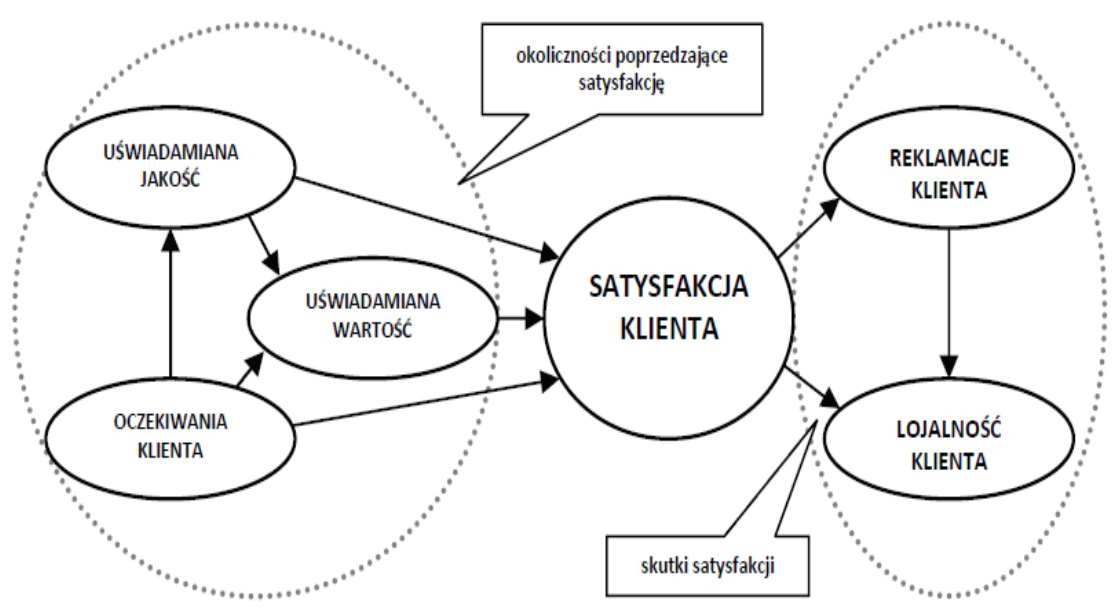

Rys. 1. Model ksztaltowania się satysfakcji klienta

Źródło: Opracowanie na podstawie [12]. 
Z rysunku 1 wynika, iż satysfakcja to rezultat uświadomionej jakości i wartości uzyskanej przez klienta, uświadomionej w oparciu o wcześniej sformułowane oczekiwania. Zidentyfikowane skutki satysfakcji mogą być pozytywne (pojawienie się satysfakcji, pozytywne odczucia, lojalność klienta) oraz negatywne (brak satysfakcji, negatywne wrażenia, reklamacje i rezygnacja $\mathrm{z}$ ponownego skorzystania $\mathrm{z}$ oferty danego przedsiębiorstwa).

$\mathrm{Na}$ podstawie przedstawionych informacji można stwierdzić, iż satysfakcja to wypadkowa potrzeb i oczekiwań klienta (kształtowanych przed usługą) oraz doświadczeń (pojawiających się po usłudze) [13].

\section{Wyniki przeprowadzonych badań - determinanty satysfakcji klientów małych firm usługowych}

Dla potrzeb badań w dniach 10-20 lutego 2018 roku wśród klientów małych firm usługowych drogą elektroniczną przeprowadzona została anonimowa ankieta, której celem było wskazanie najistotniejszych determinantów satysfakcji klientów małych firm usługowych. W sondażu diagnostycznym wzięło udział 150 respondentów, w tym 100 kobiet i 50 mężczyzn. Struktura grupy badanej przedstawiona jest $\mathrm{w}$ tabeli 1 .

Tabela 1. Struktura respondentów

\begin{tabular}{|c|c|c|c|}
\hline Wiek & Mężczyźni, \% & Kobiety, \% & Razem, \% \\
\hline $18-24$ & 30 & 10 & 40 \\
\hline $25-39$ & 23,33 & 16,67 & 40 \\
\hline $40-59$ & 13,33 & 6,67 & 20 \\
\hline $60<$ & 0 & 0 & 0 \\
\hline \multicolumn{3}{|r}{} & $\mathbf{1 0 0}$ \\
\cline { 2 - 3 }
\end{tabular}

Źródto: Opracowanie własne

Grupą dominującą wśród respondentów są kobiety w wieku 18-24 lata, stanowiące $30 \%$ ankietowanych. Warto zauważyć, iż żaden uczestnik badania nie należał do grupy osób starszych (60 i więcej lat), co może być spowodowane elektronicznym kanałem przeprowadzenia badania.

Arkusz anonimowej ankiety składał się z metryczki oraz 7 stwierdzeń, ocenianych przez respondentów za pomocą skali Likerta [14] w oparciu o założenia:

5- zdecydowanie się zgadzam,

1- zdecydowanie się nie zgadzam. 
Zdaniem respondentów, satysfakcja to ważny czynnik kształtujący jakość usług. Ze stwierdzeniem „Osiągnięta satysfakcja to według mnie najważniejszy czynnik wpływający na moją ocenę poziomu jakości usługi" zdecydowanie zgadza się $(13,33 \%)$ lub zgadza się $(35,33 \%)$ łącznie 48,66\% respondentów, w tym 58\% ankietowanych kobiet i 30\% ankietowanych mężczyzn (rys. 2). Wynik ten oznacza, iż ponad połowa pytanych kobiet oceny jakości usługi dokonuje głownie na podstawie poziomu osiągniętej satysfakcji, podobnie jak co trzeci mężczyzna. Przewaga kobiet w tym stwierdzeniu może wynikać z emocjonalnej podstawy satysfakcji. Badania [15] dowodzą, iż satysfakcja powstaje w oparciu o podłoże emocjonalne (oczekiwania, doświadczenia, empatia) oraz mierzalne parametry jakości usług (wymierne korzyści, czas, cena, termin, dostępność). Kobiety mają tendencję do podejmowania decyzji pod wpływem emocji, a mężczyźni w oparciu o podstawy techniczne. Warto zauważyć, iż co czwarty ankietowany nie ma zdania na temat satysfakcji jako decydującej d

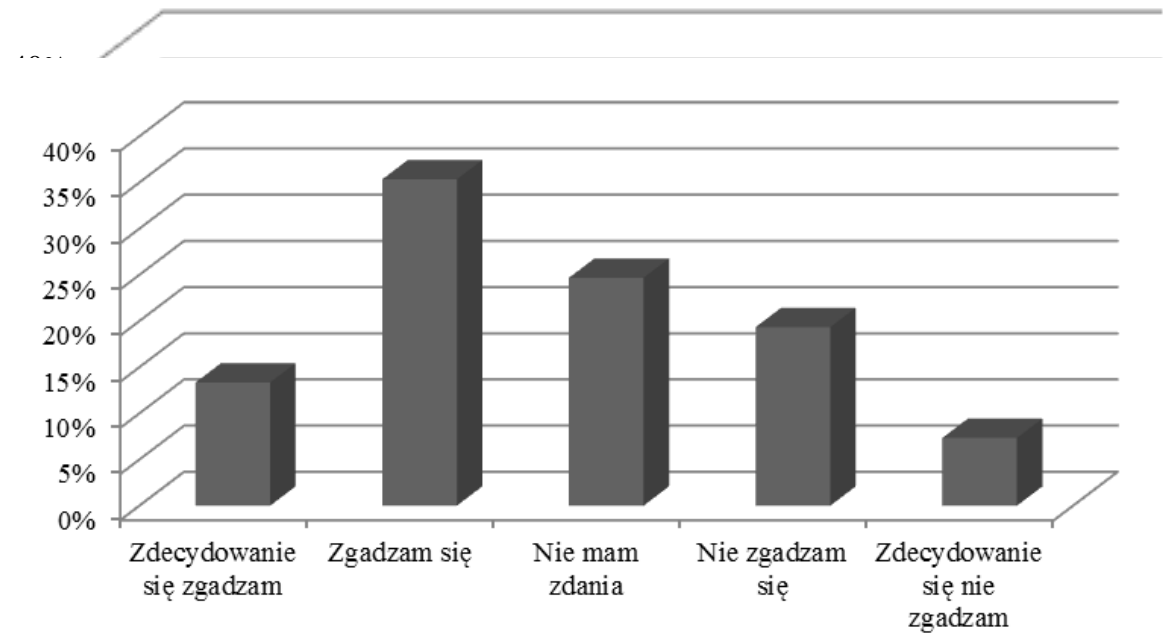

Rys. 2. Satysfakcja jako decydująca determinanta jakości usług - opinia respondentów Źródto: Opracowanie własne

Kolejne dwa stwierdzenia dotyczyły znaczenia ogółu uwarunkowań technicznych i uwarunkowań organizacyjnych jako podstaw budowania satysfakcji klienta. Uwarunkowania techniczne usługi ( $\mathrm{w}$ arkuszu ankiety wymieniono przykładowe: budynek, wyposażenie, sprzęty i narzędzia) za najważniejsze uznaje aż $56 \%$ badanych mężczyzn i 44\% badanych kobiet (rys. 3). Co ważne, ponad 30\% respondentów nie ma zdania $\mathrm{w}$ tej kwestii- wysoki odsetek kobiet $(27 \%)$ także może być argumentowany przewagą sfery emocjonalnej z jednoczesnym uwzględnieniem istotności technicznych atrybutów usługi. Warto zauważyć, iż 29\% kobiet przyznaje 
o niewielkim wpływie uwarunkowań technicznych na osiąganą przez nie satysfakcję $\mathrm{z}$ usługi.

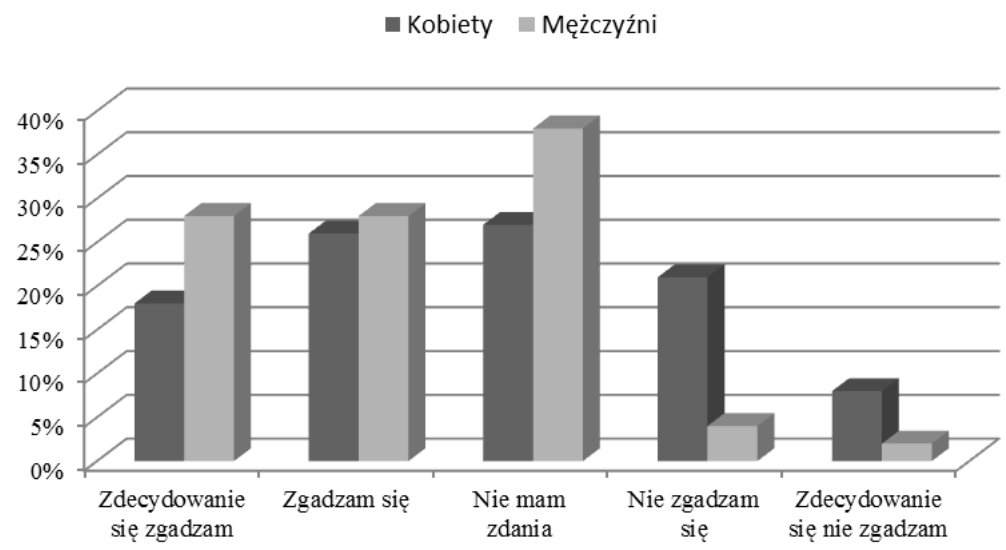

Rys. 3. Wpływ uwarunkowań technicznych na satysfakcję-opinia respondentów

Źródto: Opracowanie własne

Uwarunkowania organizacyjne jako najistotniejszą determinantę satysfakcji uznaje $55 \%$ respondentów płci żeńskiej (23\%- zdecydowanie się zgadza z tym stwierdzeniem i $32 \%$ się zgadza) oraz jedynie 36\% mężczyzn (warto jednak zauważyć, iż jedynie $6 \%$ mężczyzn się zdecydowanie z tym stwierdzeniem zgadza) (rys.4).

- Kobiety Mężczyźni

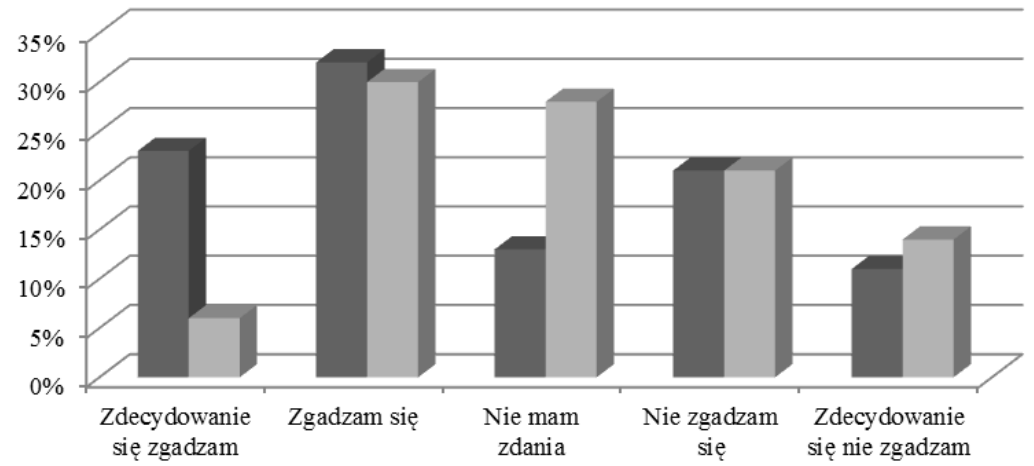

Rys. 4. Wpływ uwarunkowań organizacyjnych na satysfakcję-opinia respondentów Źródto: Opracowanie własne 
Wśród przykładowych uwarunkowań organizacyjnych usługi w arkuszu ankiety podane zostały: czas oczekiwania, organizacja przebiegu świadczenia usługi, empatia i podejście personelu. W przypadku małych lokalnych firm usługowych uwarunkowania organizacyjne mogą stanowić decydującą determinantę jakości oraz satysfakcji. Aż co trzeci ankietowany mężczyzna (28\%) nie ma zdania na temat, co może potwierdzać większe znaczenie uwarunkowań technicznych przy jednoczesnym docenieniu wartości uwarunkowań organizacyjnych. Warto dodać, iż 32\% kobiet i $35 \%$ mężczyzn nie zgadza się z powyższym stwierdzeniem.

Cenę jako najważniejszą determinantę satysfakcji postrzega prawie połowa respondentów płci żeńskiej (49\%) i ponad połowa ankietowanych mężczyzn (52\%) (rys. 5). Cena uznawana w świetle badań uznawana jest za ważny czynnik decyzyjny odnośnie zakupu produktu lub skorzystania z usługi [16].

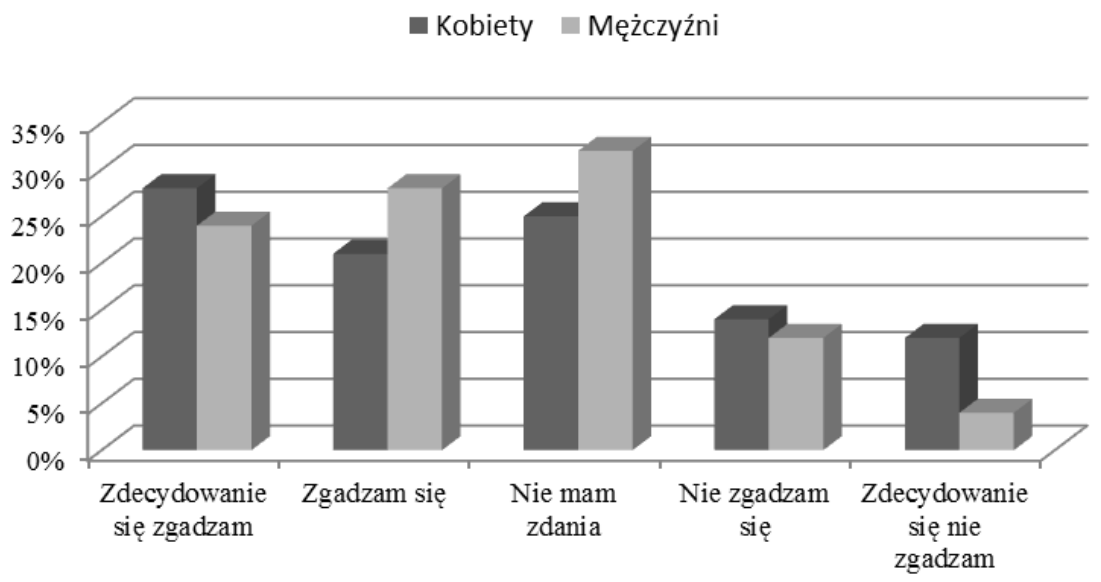

Rys. 5. Cena jako najistotniejsza determinanta satysfakcji - opinia respondentów

Źródto: Opracowanie własne

W związku z ogromną konkurencją w sektorze MSP, cena uznawana jest za ważny czynnik konkurencyjności. Najczęściej porównywana jest w relacji cenajakość, złożoność pojęcia satysfakcji powoduje jednak możliwość postrzegania ceny jako jednej z jej istotnych determinantów. Oznacza to, iż klient może uzyskać satysfakcję z usługi jeśli jest zadowolony z kosztu, jaki poniósł na jej realizacje. Warto dodać, iż wyniki ankiety niekoniecznie muszą być związane z niską ceną jako czynnikiem kształtującym satysfakcję, ważne, by była ona adekwatna do oczekiwań klienta i żeby był w stanie ją zapłacić postrzegając usługę jako ofertę wartą danej ceny. Należy także wspomnieć, iż co czwarta kobieta i $15 \%$ ankietowanych mężczyzn nie traktują ceny jako decydującej determinanty satysfakcji. 
Ze stwierdzeniem „Na satysfakcję największy wpływ ma niezawodność usługi’” zgadza się aż 76\% respondentów wśród kobiet (w tym 39\% zdecydowanie się zgadza) oraz $84 \%$ respondentów wśród mężczyzn (w tym prawie połowa ankietowanych zdecydowanie się zgadza) (rys. 6).

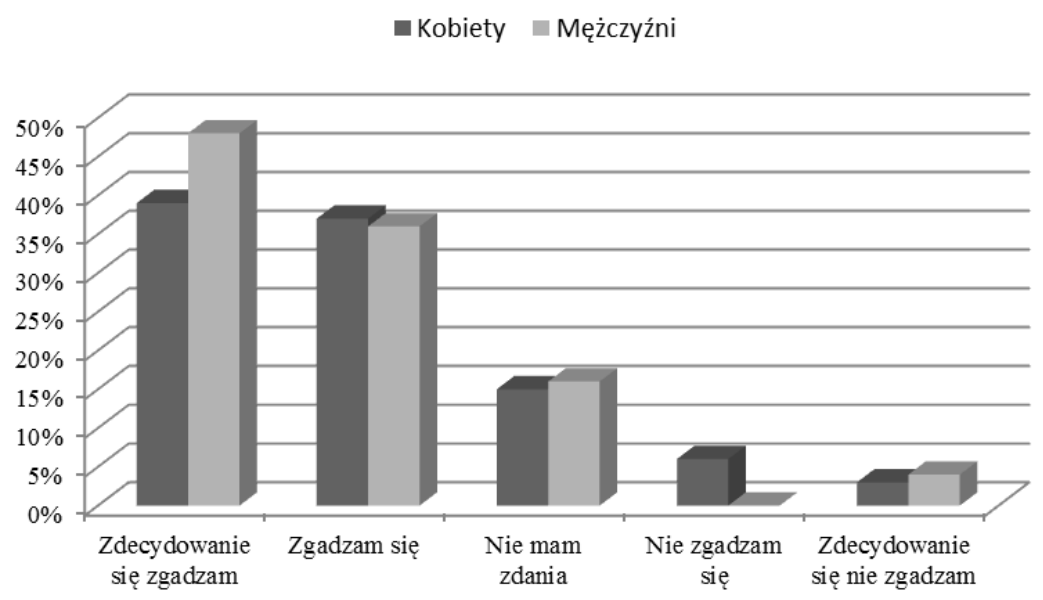

Rys. 6. Niezawodność jako najistotniejsza determinanta satysfakcji - opinia respondentów Źródto: Opracowanie własne

Dla potrzeb wyjaśnienia pojęcia w arkuszu ankiety zawarta została krótka charakterystyka pojęcia niezawodności usługi - „świadczenie jej terminowo i rzetelnie'’. Wyniki te, iż satysfakcja klienta w największym stopniu zależy głównie od przebiegu procesu świadczenia usługi pod kątem czasu, sprawności i efektywności. Należy zauważyć, iż żaden mężczyzna poddany badaniu nie zaprzecza istotności niezawodności w kształtowaniu satysfakcji z usługi.

Kolejne pytanie dotyczyło dostępności usługi (rys. 7).

Wśród determinantów jakości usług wiele opracowań wskazuje dostępność usługi. W arkuszu ankietowym dostępność usługi określona została poprzez przykładowe jej cechy, takie jak: lokalizacja przedsiębiorstwa usługowego, godziny otwarcia firmy, możliwości kontaktu z usługodawcą itp.

Respondenci wskazali, iż dostępność usługi nie jest najważniejszą determinantą kształtującą satysfakcję. Aż 58\% ankietowanych, w tym 54\% kobiet i 60\% mężczyzn nie zgadza się z powyższym stwierdzeniem. Jako, iż co czwarta ankietowana i $14 \%$ ankietowanych nie ma zdania na ten temat, odsetek respondentów wskazujących dostępność ługi jako istotną determinantę satysfakcji należy uznać za niewielki. 


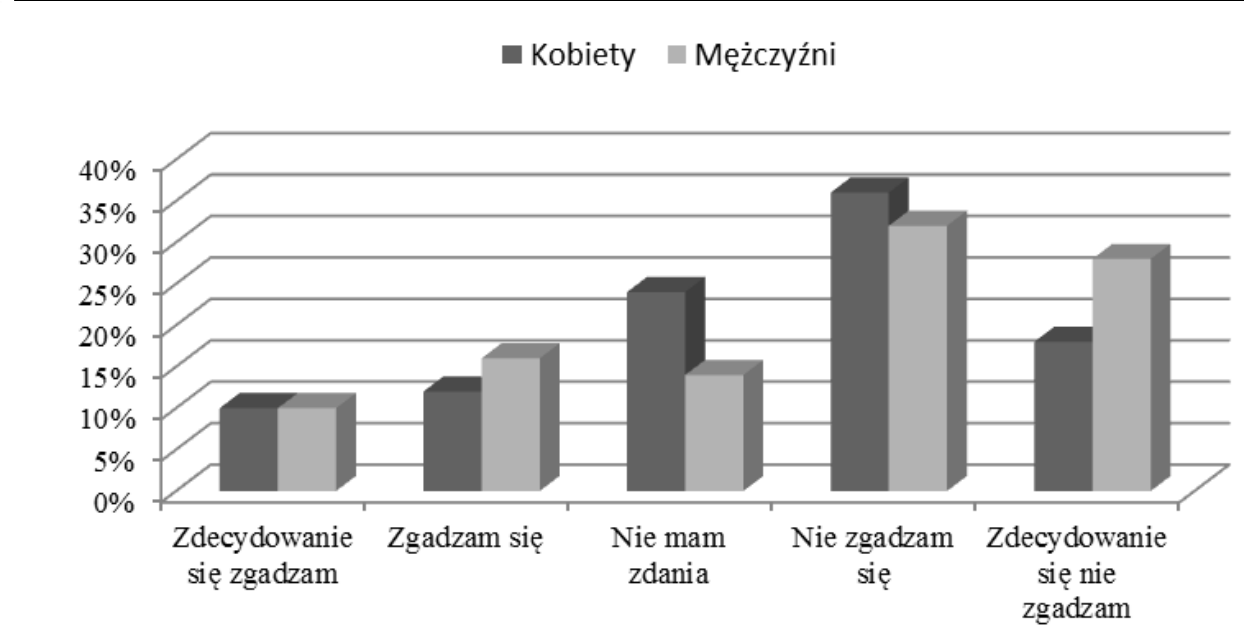

Rys. 7. Dostępność jako najistotniejsza determinanta satysfakcji - opinia respondentów Źródto: Opracowanie własne

Bezpieczeństwo $\mathrm{w}$ usługach $\mathrm{w}$ ostatnich latach staje się zagadnieniem podejmowanym w badaniach specjalistów z wielu dziedzin. Coraz bardziej świadomi klienci w wyborze przedsiębiorstwa, z którego usług skorzystają, biorą pod uwagę coraz szerszy zakres czynników. W ramach tego pytania badacz chciał uzyskać informacje odnośnie znaczenia bezpieczeństwa w kształtowaniu satysfakcji z usługi (rys. 8).

" Kobiety $\quad$ Mężczyźni

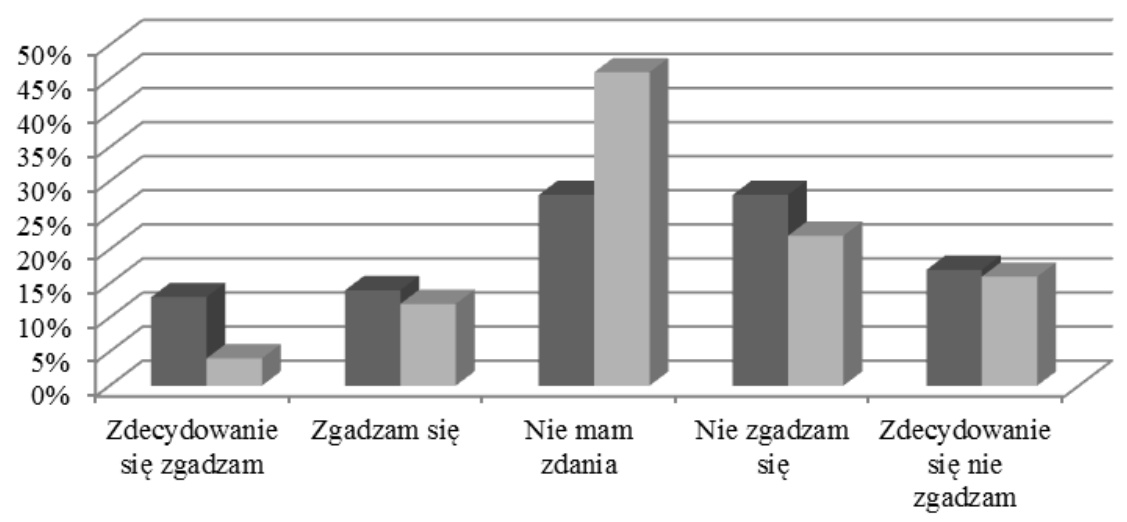

Rys. 8. Bezpieczeństwo jako najistotniejsza determinanta satysfakcji - opinia respondentów Źródto: Opracowanie własne 
W odpowiedziach respondentów dostrzec można zdezorientowanie powyższym stwierdzeniem. Ponad połowa ankietowanych (51\%), w tym $28 \%$ kobiet i $46 \%$ mężczyzn nie ma zdania na temat bezpieczeństwa jako najistotniejszej determinanty satysfakcji $\mathrm{z}$ usługi. W przypadku odpowiedzi deklarujących opinię, przeważają opinię o braku zgody z tym stwierdzeniem (45\% kobiet i 19\% mężczyzn). Zauważyć należy, iż zapewnienie bezpieczeństwa należy do jednej $\mathrm{z}$ podstawowych potrzeb ludzkich w piramidzie Maslowa. Przedstawione wyniki nie muszą jednak świadczyć o niedostrzeganiu istotności kwestii bezpieczeństwa w usługach, mogą być wynikiem identyfikacji czynników ważniejszych w kształtowaniu satysfakcji z powodu braku negatywnych doświadczeń związanych $\mathrm{z}$ pojawieniem się zagrożeń $\mathrm{w}$ trakcie świadczenia usług.

\section{Podsumowanie}

Satysfakcja jako istotna determinanta jakości usług to wielowymiarowe pojęcie. $\mathrm{Z}$ badań literaturowych wynika, iż kształtowana jest $\mathrm{w}$ trakcie złożonego procesu, w oparciu o techniczne mierzalne parametry usług oraz emocjonalne aspekty klienta jako wynik porównania potrzeb i oczekiwań formułowanych przed skorzystaniem z usługi $\mathrm{z}$ faktycznymi doświadczeniami nabytymi po zakończonym procesie. Przeprowadzone badania empiryczne wśród 150 klientów małych firm usługowych pozwoliły na wskazanie następujących wniosków:

1. Satysfakcja klienta małego przedsiębiorstwa usługowego będącego mężczyzną kształtowana jest głównie w oparciu o zadowolenie z uwarunkowań technicznych usługi, a klienta będącego kobietą - głównie poprzez zadowolenie z uwarunkowań organizacyjnych usługi.

2. Niezawodność usługi, rozumiana jako terminowość i rzetelność jej świadczenia to główna determinanta satysfakcji wśród klientów małych firm usługowych.

3. Cena stanowi ważny czynnik budujący satysfakcję z usługi wśród klientów obu płci.

4. Dostępność usługi nie jest najistotniejszą determinantą budowy satysfakcji klientów małych firm usługowych.

5. Klienci małych firm usługowych nie rozważali bezpieczeństwa jako głównego kryterium kształtowania satysfakcji, o czym świadczy wysoki odsetek odpowiedzi „nie mam zdania”. 


\section{Literatura}

[1.] Smolarek M.: Wybrane aspekty rozwoju małych i średnich przedsiębiorstw. ZN WSH Zarządzanie, nr (3) 2015, s. 3-38.

[2.] Dietrich A., Kruger J.J.: Long-Run Sectoral Development-Time Series Evidence For Germany Economy. Jena Economic Research Papers, 013-2008, s.1-25.

[3.] Kachniewska M.: Modele jakości ustug a specyfikacja produkty turystycznego. [w:] Nowakowska A., Przydział M. (red.): Turystyka $w$ badaniach naukowych. Prace ekonomiczne WSIiZ, Rzeszów 2006, s. 303-319.

[4.] Kowalik K., Klimecka-Tatar D.: Wplyw procesu obstugi klienta na ksztattowanie funkcjonalnej jakości ustug. [w:] Ulewicz R., Sygut P. (red.). Instrumenty doskonalenia w zarządzaniu. Oficyna Wydawnicza SMJiP, Częstochowa 2016, s. 4657.

[5.] Stoma M.: Modele i metody pomiaru jakości ustug. Q\&R Polska, Lublin 2012.

[6.] Krzemień E., Wolniak R.: Zarządzanie jakościa $w$ sektorze ustug finansowych. Wyższa Szkoła Bankowości i Finansów, Bielsko-Biała 2004.

[7.] Shaw R.: Nowe spojrzenie na marketing. Studia Emka, Warszawa 2001.

[8.] Mazurek-Łopacińska K.: Zachowania nabywców i ich konsekwencje marketingowe. PWE, Warszawa 2003.

[9.] Borkowski S., Wszendybył E.: Jakość i efektywność ustug hotelarskich. PWN, Warszawa 2007.

[10.] Haffer R.: Satysfakcja klientów i jej pomiar. [w:] Sudoł S., Szymczak J., Haffer M. (red.). Marketingowe testowanie produktów. PWE, Warszawa 2000.

[11.] Penc J.: Marketing ustug. Uniwersytet Szczeciński, Szczecin 2005.

[12.] Śmiatacz K.: Badanie satysfakcji klientów na przykładzie rynku ustug telefonii komórkowej w Polsce. Uniwersytet Technologiczno-Przyrodniczy w Bydgoszczy, Bydgoszcz 2012.

[13.] Jasiulewicz-Kaczmarek M., Misztal A.: Projektowanie i integracja systemów zarzadzania projakościowego. Politechnika Poznańska, Poznań 2014.

[14.] Sullivan G., Artino Jr R.: Analyzing and interpreting Data From Likert-Type Scales. Journal of Graduate Medical Education, vol. 5, no 4, 2013, s. 541-542.

[15.] Wojtas-Klima M.: Gdy emocje już opadna- czyli co wptywa na podejmowanie decyzji. Zeszyty Naukowe Politechniki Śląskiej. Seria Organizacja i Zarządzanie, nr 71, 2014, s. 315-325.

[16.] Gajewska P., Kajstura M., Lebioda G. Jakość jako determinanta w procesie zakupu. Zeszyty Naukowe Humanitas. Zarządzanie, nr 2, 2013, s. 235-248. 


\title{
DETERMINANTS OF THE SATISFACTION IN THE OPINION OF SMALL ENTERPRISES' CUSTOMERS
}

\begin{abstract}
The objective of the article is to present the determinants of the satisfaction of service quality in the opinion of small enterprises' customers. The first part contains the theoretical framework of the satisfaction characteristic as a factor of service quality evaluation. Afterwards, the results of empirical research have been presented. Anonymous survey, regarding the evaluation of service satisfaction determinants, has been conducted among one hundred and fifty customers of small enterprises. The results clearly indicated high importance of satisfaction in the assessment of service quality, built mainly on the basis of technical conditions (among men) and organizational (among women), taking into account the reliability and price of the service.
\end{abstract}

Key words: development, satisfaction, service quality, small enterprises

Data przestania publikacji do Redakcji: 07.12.2018

Data akceptacji publikacji przez Redakcję: 22.01.2019

DOI: 10.30657/qpi.2019.10.02 